\title{
Opportunity Costs of Forest Conservation in Wilberforce Island, Niger Delta, Nigeria
}

\author{
ANDREW, CE; *BARIWENI, PA \\ Department of Geography \& Environmental Management \\ Niger Delta University, Wilberforce Island, Bayelsa State \\ *Corresponding Author Email: andrewcomforte@gmail.com;* pbariweni@yahoo.com
}

\begin{abstract}
The objectives of this study is to assess the acceptability and opportunity cost of forest conservation program as well as the impact of alternative source of income on forest conservation in the Wilberforce Island. Data were obtained from five communities through self-administered questionnaires and analysed as Proportions and ranked. Results showed that only $40.8 \%$ of the population favoured forest conservation, while $51.2 \%$ rejected forest conservation. However, when asked if forest conservation program would be accepted if an alternative source of income, equivalent to the net present value of forest conservation was provided, $64.0 \%$ of the respondents accepted forest conservation. In spite of increased acceptance of forest conservation following the provision of an alternative source of income, only $46.4 \%$ of the respondents believed this would help in preventing further deforestation in the Wilberforce Island. An assessment of the income level of respondents showed an average monthly income of $\$ 33,640.00$ ( $\$ 403,680.00 / \$ 1,122.00 @ \$ 360.00 / \$$ per annum). For farmers and loggers, average monthly income was $\$ 23,648.00$ ( $\$ 283,776.00 / \$ 788.00$ per annum) and $\$ 46,577.00$ ( $\$ 558,924.00 / \$ 1,553.00$ per annum). This income level was estimated to be the opportunity cost of forest conservation in the Wilberforce Island. It was concluded that additional measures and an alternative income higher than currently earned can make forest conservation possible in the area.
\end{abstract}

\section{DOI: https://dx.doi.org/10.4314/jasem.v22i12.16}

Copyright: Copyright $\odot 2018$ Andrew and Bariweni. This is an open access article distributed under the Creative Commons Attribution License (CCL), which permits unrestricted use, distribution, and reproduction in any medium, provided the original work is properly cited.

Dates: Received: 18 November 2018; Revised: 20 December 2018; Accepted 28 December 2018

Keywords: Forest Conservation, deforestation, opportunity cost, Wilberforce Island

Deforestation is a global problem driven by rapid population growth, agricultural expansion, use of fuelwood, etc. (Akinyemi, 2013; FAO, 2010). This problem is known to lead to biodiversity and habitat loss, increased greenhouse gas emissions and climate change, decrease in quality of life, etc (Holland, n.d). Several solutions including reforestation, planned logging, creation of forest reserves and conservation have been proffered to solve the problem of deforestation worldwide (Forest Conservation in the United States, 2015). As stated by the Food and Agriculture Organization (FAO, 2015), forest conservation, is a very important strategy for halting biodiversity loss, mitigating climate change, and securing the continued availability of essential products and resources for people who depend on forests directly or indirectly for their livelihood and other needs.

This however comes at a cost, which is known as the opportunity cost. The opportunity cost of forest conservation is the net income per hectare per year or the net present value (NPV) that is sacrificed because of not logging (or logging more sustainably) or not converting forest land to agriculture. Opportunity costs, which vary according to the drivers of deforestation in a specific region or country (Olsen \& Bishop, 2009) is thus the profit gained from continuing "business as usual". Opportunity costs are generally treated as the most important cost component of Reducing Emissions from Deforestation and Degradation (REDD) and are often the only costs estimated given current uncertainty regarding the future design of REDD and hence the costs associated with implementation and transactions (Olsen \& Bishop, 2009).

Current studies have shown massive deforestation and their causes in the Wilberforce Island (Bariweni \& Andrew, 2017) and the Yenagoa Metropolis, Niger Delta (Bariweni and Amukali, 2017). However, it is not certain, if forest conservation programs will be accepted by residents and whether such efforts can help to reduce deforestation activities in the area. It is also not certain what the opportunity cost of such a conservation effort will be. The objectives of this study is therefore to assess the acceptability and opportunity cost of forest conservation program as well as the impact of alternative source of income (opportunity cost) on forest conservation in the Wilberforce Island. 


\section{MATERIALS AND METHODS}

The study area: The Wilberforce Island, is located from latitude $4^{\circ} 51^{\prime} \mathrm{N}$ to $5^{\circ} 02^{\prime} \mathrm{N}$ and from longitude $6^{\circ}$ $04^{\prime} \mathrm{E}$ to $6^{\circ} 17^{\prime} \mathrm{E}$ (Figure 1). The Island cuts across Kolokuma-Opokuma, Yenagoa, Southern Ijaw and Sagbama Local Government Areas in Bayelsa State and is drained mainly by the Nun River which is a distributary of River Niger. Vegetation of the area, which is the tropical rainforest type is interspersed by fresh water swamps. The major occupation of the people in the area include farming, fishing and lumbering. However, some individuals switched over to civil service jobs, trading, etc. following the establishment of the Niger Delta University in the Island in 2001. Because of farming and lumbering, deforestation remains a serious problem. To ensure sustainable ecosystem services, there is a very serious need for forest conservation.

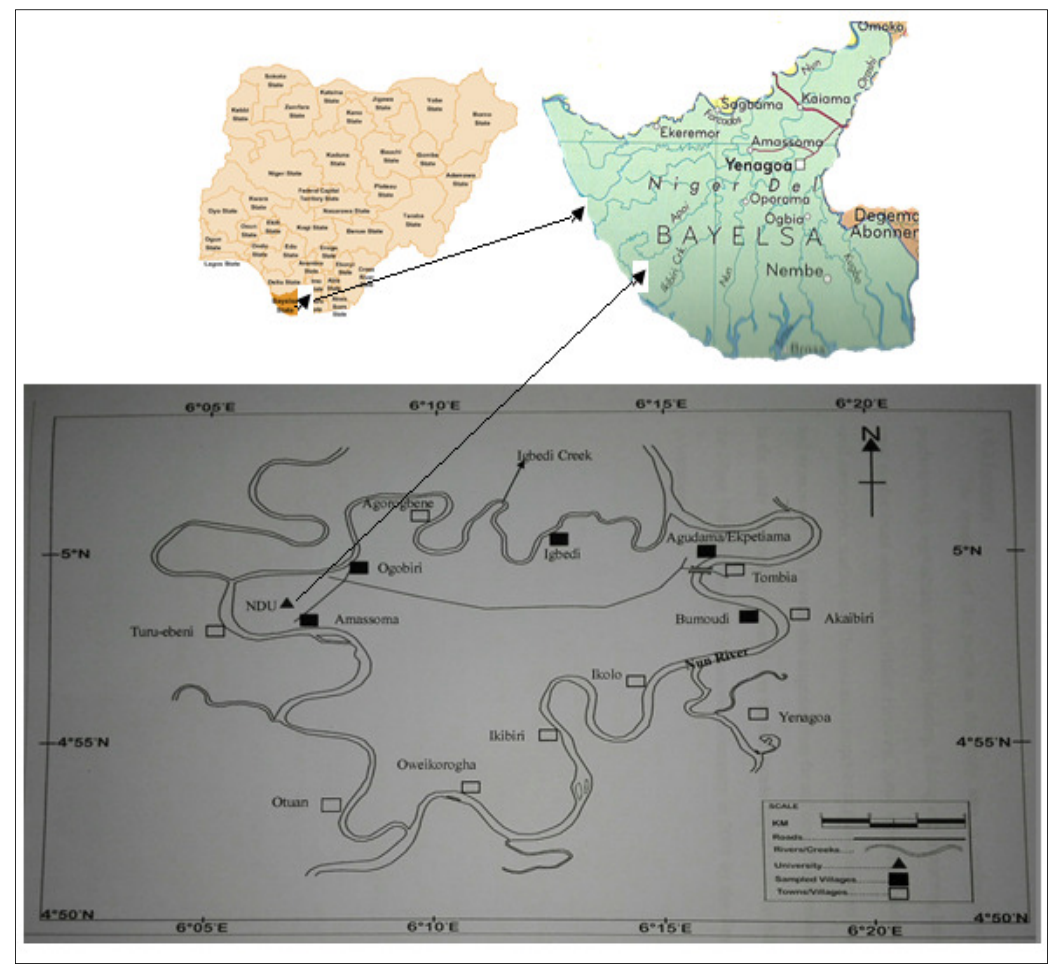

Fig 1: The Wilberforce Island, Nigeria

Method of study: The study used a survey research design to assess the level of acceptance of forest conservation and the opportunity cost of forest conservation from five communities (Amassoma, Ogobiri, Agudama/Ekpetiama, Igbedi and Bumoudi) which were selected based on accessibility using the purposive sampling technique. One hundred and twenty-five (125) self-administered questionnaires were used for data collection from respondents. The primary data obtained were analysed as proportions and ranked.

\section{RESULTS AND DISCUSSION}

Information concerning the socio-demographic characteristics of respondents in the Wilberforce Island showed that $15.0 \%$ of the respondent had primary education, $52.0 \%$ secondary education, $15.0 \%$ tertiary education, while $18.0 \%$ had no formal education. With respect to occupation, results indicated that $51.2 \%$ were farmers, $10.4 \%$ were loggers, $10.4 \%$ were combining civil service jobs with farming, 7.2 were self - employed, while others were traders, unemployed, and students. The observed dominant occupation and high level of educations points to the observed high level of awareness of deforestation activities in the Wilberforce Island and this is confirmed by Bariweni and Andrew (2017).

Results further revealed that $98.4 \%$ of the respondents benefited from the forest, with food and fibre ranking highest followed by firewood, herbs and timber respectively (Table 1). The observed high level of awareness of deforestation activities was also linked to the fact that majority of the respondents benefitted from forest resources. Because of the benefits derived from the forest by majority of the people, the need for forest conservation was not a popular option in the area. Results confirmed that only $40.8 \%$ of the 
population favoured a forest conservation program, while $51.2 \%$ rejected forest conservation. However, when asked if forest conservation program would be accepted if an alternative source of income equivalent to the net present value of forest conservation was provided, $64.0 \%$ of the respondents accepted forest conservation while $36.0 \%$ still rejected forest conservation (Table 2). Conserving ecosystem services require foregoing alternative values and land uses, such as timber extraction or agricultural production (Pagiola, et al., 2002). As forest conservation was not a popular option, the study assessed the impact of an alternative source of income on level of acceptance of a forest conservation program. Data obtained from this interrogation showed a $29.69 \%$ decrease in the number of respondents that had formerly rejected forest conservation, and a $100 \%$ decrease in the number of respondents who were previously undecided about forest conservation (Table 2). What is more, the number of respondents that accepted forest conservation increased by $56.86 \%$ when the idea of an alternative source of income equivalent to the net present value of forest conservation was introduced.

Table 1: Distribution of Resources Enjoyed from the Forest in the Wilberforce Island

\begin{tabular}{lllll}
\multicolumn{5}{c}{ Table 1: Distribution of Resources Enjoyed from the Forest in the Wilberforce Island } \\
\hline \multirow{2}{*}{ Forest Resources } & $\begin{array}{l}\text { Number } \\
\text { Respondents }\end{array}$ & $\begin{array}{l}\text { Expected } \\
\text { of Respondents }\end{array}$ & $\begin{array}{l}\text { Percentage of } \\
\text { Respondents (\%) }\end{array}$ & Rank \\
\hline Food \& Fibre & 110 & 125 & 88.0 & 1 \\
Firewood & 100 & 125 & 80.0 & 2 \\
Herbs & 85 & 125 & 68.0 & 3 \\
Timber & 58 & 125 & 46.4 & 4 \\
Storm Protection & 46 & 125 & 36.8 & 5 \\
Air Purification & 21 & 125 & 16.8 & 6 \\
Erosion Control & 20 & 125 & 16.0 & 7 \\
Others (e.g. inspiration, & 5 & 125 & 4.0 & 8 \\
aesthetic value, etc.) & 4 & 125 & 3.2 & 9 \\
Latex & (Source: Authors'fieldwork, 2016) &
\end{tabular}

Table 2: Impact of alternative source of income on the Acceptance of Forest Conservation

\begin{tabular}{|c|c|c|c|c|c|c|}
\hline \multirow[b]{2}{*}{ Responses } & \multicolumn{6}{|c|}{ Number of Respondents } \\
\hline & $\begin{array}{l}\text { Before introduction of } \\
\text { alternative source of } \\
\text { income }\end{array}$ & $(\%)$ & $\begin{array}{l}\text { After introduction of } \\
\text { alternative source of } \\
\text { income }\end{array}$ & $(\%)$ & $\begin{array}{l}\text { Change in No. } \\
\text { of } \\
\text { Respondents }\end{array}$ & $\begin{array}{l}(\%) \\
\text { Change }\end{array}$ \\
\hline Yes & 51 & 40.8 & 80 & 64 & 29 & 56.86 \\
\hline No & 64 & 51.2 & 45 & 36 & -19 & -29.69 \\
\hline Not Sure & 10 & 8.0 & - & - & -10 & -100.00 \\
\hline Total & 125 & & 125 & & & \\
\hline
\end{tabular}

Table 3: The Distribution of Estimated Monthly Income among Respondents

\begin{tabular}{|c|c|c|c|c|c|c|c|}
\hline $\begin{array}{l}\text { Occupation/Estimated } \\
\text { Monthly Income (N) }\end{array}$ & $\begin{array}{l}8 \\
8 \\
8 \\
1 \\
8 \\
8 \\
8\end{array}$ & $\begin{array}{l}8 \\
8 \\
0 \\
i \\
1 \\
8 \\
8 \\
\text { ¿ }\end{array}$ & $\begin{array}{l}8 \\
8 \\
8 \\
\infty \\
1 \\
8 \\
\varnothing \\
\\
\end{array}$ & $\begin{array}{l}8 \\
8 \\
0 \\
0 \\
1 \\
8 \\
8 \\
0 \\
\infty\end{array}$ & $\begin{array}{l}8 \\
8 \\
8 \\
8 \\
1 \\
8 \\
8 \\
8 \\
= \\
=\end{array}$ & 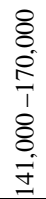 & Total \\
\hline Farmer & 53 & 3 & 3 & 1 & 2 & 2 & 64 \\
\hline Logger & 5 & 5 & 1 & & & 2 & 13 \\
\hline Trader & & 2 & 1 & & & & 3 \\
\hline Civil Servant & & 2 & & 1 & & & 3 \\
\hline Pensioner & & & & & & & - \\
\hline Self-employed & 5 & 1 & 1 & 2 & & & 9 \\
\hline Logger/farmer & 2 & 3 & & & & & 5 \\
\hline Civil servant/farmer & 1 & 9 & 2 & 1 & & & 13 \\
\hline Private worker/farmer & & 2 & & & & & 2 \\
\hline Pensioner/farmer & 1 & & & & & 2 & \\
\hline Trader/farmer & & 3 & & & & & \\
\hline Self-employed/farmer & 2 & 3 & 2 & & & & \\
\hline Total & 69 & 33 & 10 & 5 & 2 & 6 & 125 \\
\hline
\end{tabular}

This result has given some credence to the views of Porras (2012) and the UN-REDD Program (2012) that ecosystem resources can be better protected if landowners received a financial payment as compensation to private landowners for the opportunity costs of not destroying the forests. This is because, although the provision of an alternative source of income increased the rate of acceptance of forest conservation, results indicated that only $46.4 \%$ of the respondents believed this would help in 
preventing further deforestation in the Wilberforce Island; $15.2 \%$ believed this would not prevent deforestation, while $38.4 \%$ could not provide any guarantee of the impact of an alternative source of income on prevention of deforestation in the area.

The study also interrogated the preferred alternative sources of income by respondents who favoured forest conservation. Data showed that the preferred options were mainly monthly payments $(38.75 \%)$; provision of capital for business $(28.75 \%)$; provision of employment (13.75\%); and others including annual payments, provision of business pack, etc. As stated earlier, the opportunity cost of forest conservation is the net income per hectare per year or the net present value that is sacrificed because of not logging or not converting land to agriculture. This cost was estimated through the assessment of the average monthly income of the respondents (Table 3). Results showed an average monthly income of $\$ 33,640.00$ ( $\$ 403,680.00$ per annum). For farmers and loggers, average monthly income was $\$ 23,648.00$ ( $\$ 283,776.00$ per annum) and $\$ 46,577.00$ (\$558,924.00 per annum) respectively. Thus, the opportunity cost of forest conservation for landowners in the Wilberforce Island area was estimated to range from $\$ 283,776.00$ to $\$ 522,924.00$ per annum for forest conservation programme to succeed.

Conclusion: It was concluded that forest conservation was not acceptable in the Wilberforce Island. However, the provision of an alternative source of income, equivalent to the net present value of forest conservation, can make forest conservation possible. As there was no assurance that this will curb further deforestation, a higher monthly income (higher opportunity cost) than currently grossed and other additional measures need to be put in place for forest conservation program to succeed in the area.

\section{REFERENCES}

Akinyemi, FO (2013). An Assessment of Land-use Change in Cocoa Belt of South-west Nigeria. Intern. J. Remote Sensing. 34(8), 2858-2875.
Bariweni, PA; Andrew, CE (2017): Land use/Land Cover Changes in the Wilberforce Island, Bayelsa State, Nigeria. J. Appl. Sci. Environ. Manage. 21 (6) 1063 - 1066

Bariweni, PA; Amukali O (2017): Wetland Changes in Yenagoa Metropolis, Bayelsa State, Nigeria. Port Harcourt J. Soc. Sci. 7, (1), 15-19

Food and Agriculture Organization (FAO). (2010). Global Forest Resources Assessment 2010. Main report FAO Forestry Paper 163. http://www.fao.org/docrep/013/i1757e/i1757e.pdf

Forest Conservation in the United States. (2015). Retrieved from http://en.m.wikipedia.org/wiki/Forest_Conservati on_in_the_United_States 15/10/2015.20:45

Holland, E (n.d): Deforestation - causes, effects and solutions. Futurism. Retrieved from https://futurism.media/deforestation-causeseffects-and-solutions 9/4/18. 12.10

Olsen, N; Bishop, J. (2009). The Financial Costs of REDD: Evidence from Brazil and Indonesia. IUCN. Published by IUCN, Gland, Switzerland

Pagiola, S; Bishop, J; Landel-Mills, N.(Eds). (2002). Selling Forest Environmental Services: Marketbased Mechanisms for Conservation and Development. London: Earthscan Publication Ltd.

Porras, I. (2012). Costa Rica: Growing money on trees. Natural resource management. Sustainable market. Viewed at http://www.iied.org/costa-ricagrowing-money-on-trees at 00:12, 21/08/2015

UN-REDD Programme. (2012). U.N Collaborative Programme on Reducing Emissions from Deforestation and Forest Degradation in Developing Countries. Nigeria REDD+ Readiness Programme. National Programme Document. Federal Republic of Nigeria. 